\title{
Effect of intestinal resection on serum antibodies to the mycobacterial 45/48 kilodalton doublet antigen in Crohn's disease
}

\author{
G Kreuzpaintner, P K Das, A Stronkhorst, A W Slob, G Strohmeyer
}

\begin{abstract}
Interest in the role of mycobacterial infection in Crohn's disease has been revived by the cultural detection of Mycobacterium paratuberculosis in patients with Crohn's disease. This hypothesis was examined serologically using assays with high specificity for Crohn's disease. The effect of intestinal resection on serum antibodies specific for Crohn's disease was investigated with an immunoblot assay and an enzyme linked immunosorbent assay using the $45 / 48$ kilodalton doublet antigen of Mycobacterium tuberculosis. Antibodies were detected in $64.7 \%$ of patients with Crohn's disease $(n=17)$, $10 \%$ of patients with ulcerative colitis $(n=10), 5 \%$ of patients with carcinoma of the colon $(n=20)$, and none of 10 healthy subjects with the immunoblot assay. Statistical comparison of the Crohn's disease patients with each control group resulted in $\mathbf{p}=\mathbf{0 . 0 0 0 0 2 3 6}$. Immunoglobulin $G$ was essentially unchanged 75 days (mean) after surgery. After more than 180 days, however, the antibody response was reduced in all of five patients studied, and was no longer demonstrable in two of them (40\%). Simultaneously, the Crohn's disease activity index (CDAI) decreased. Both the high specificity of this assay for Crohn's disease and the diminished antibody response after intestinal resection in parallel with decreased CDAI support a mycobacterial aetiology of Crohn's disease.

(Gut 1995; 37: 361-366)
\end{abstract}

Keywords: Crohn's disease, intestinal resection, Mycobacterium paratuberculosis.

Many attempts have failed to detect increased antibodies directed to crude antigens of various disrupted mycobacteria in patients with Crohn's disease. ${ }^{1-7}$ Similar results were obtained with purified common mycobacterial antigens like lipoarabinomannan ${ }^{89}$ or the membrane glycoprotein $\mathrm{A} 60^{10}$ as well as purified antigens of Mycobacterium paratuberculosis. ${ }^{611}$ Increased immunoglobulin G (IgG) directed to the purified protein derivative of not only $M$ paratuberculosis ${ }^{7}$ but also other mycobacteria have been found in Crohn's disease. ${ }^{12}$ Increased IgA and IgM antibodies to the soluble antigens of $M$ tuberculosis in patients with Crohn's disease were reported by Grange et al. ${ }^{13}$ Only Thayer et al ${ }^{14}$ found an increased serological reactivity to a protoplasmic antigen of $M$ paratuberculosis in patients with Crohn's disease using an enzyme linked immunosorbent assay (ELISA). But Cho et al ${ }^{15}$ failed to duplicate these results using the same antigen and an ELISA. Also Haga et al ${ }^{16}$ were unable to reproduce the reported data and found that the antibody titres to $M$ paratuberculosis of Crohn's disease patients and controls did not differ in any immunoglobulin class.

Using an immunoblot technique with $M$ paratuberculosis antigens separated by polyacrylamide gel electrophoresis, Whitehead ${ }^{17}$ found that identical antigen bands were recognised by the serum samples from the Crohn's disease patients examined and cattle infected naturally with $M$ paratuberculosis. From one of the patients with Crohn's disease $M$ paratuberculosis had been isolated. Finally, Das et al ${ }^{18}$ showed with an immunoblot assay that IgG directed to the 45/48 kilodalton doublet antigen of $M$ tuberculosis were present in $75 \%$ of the patients with Crohn's disease compared with $20 \%$ in leprosy, $15 \%$ in tuberculosis, $20 \%$ in other bowel diseases, and $15 \%$ in systemic lupus erythematosus and rheumatoid arthritis. Serum of these patients showed preferential reactivities to other mycobacterial antigens to which Crohn's disease serum had no significant reaction. In addition, the immunoreactive 45/48 kilodalton doublet antigen was also present in $M$ bovis bacille Calmette-Guérin (BCG), $M$ avium, and $M$ paratuberculosis. The same investigators developed an ELISA to measure IgG antibodies to a gel purified $45 / 48$ kilodalton doublet antigen of $M$ tuberculosis in patients' serum. They found increased IgG directed to this antigen pair in $65 \%$ of patients with Crohn's disease compared with less than $8 \%$ in ulcerative colitis, less than $5 \%$ in diverticulitis, and less than $3 \%$ in carcinoma of the colon (unpublished findings). On the basis of both assays we investigated the influence of intestinal resection on the presence of these antibodies in patients with Crohn's disease.

\section{Methods}

\section{PATIENTS}

Serum samples of 17 patients who underwent intestinal resection for Crohn's disease (nine male, eight female; mean (SD) age $30(12 \cdot 3)$ years; range, 16-61) were obtained immediately or shortly before surgery (in two patients 22 days and in one patient 14 days before operation). Postoperatively 28 samples of all 
17 patients were acquired after 284 (508) days (mean (SD); range 5-1994 days), two each in five patients, three each in three patients. The diagnosis of Crohn's disease had been established by clinical criteria as well as $x$ ray, endoscopy, and histological assessment. The average duration of disease was $10(6 \cdot 2)$ years (range 1.7-25.6). In two patients only the ileum or the colon were affected and in 13 patients the large and small bowel were affected. In five patients the terminal ileum and the right hemicolon, in three patients the terminal ileum and caecum (in one of these additionally the sigmoid colon), in two patients a part of the ileum or the colon without sigmoid colon and rectum (in one of these additionally the terminal ileum) were resected. The resection of a previous anastomosis (one jejunum and transverse colon, one ileum and transverse colon, one ileum and ascending colon with abdominoperineal proctectomy), the resection of an ileal loop, and the left hemicolon as well as a sigmoidectomy was performed. At the time of surgery eight patients received immunosuppressive treatment: seven with systemic adrenocortical corticosteroids (five, fluocortolone $5-30 \mathrm{mg} / \mathrm{day}$, two methylprednisolone $10-16 \mathrm{mg} /$ day, in one of these additionally betamethasone enema $(2.5 \mathrm{mg} / \mathrm{day}))$, and one with azathioprine (50 $\mathrm{mg} /$ day). Up to 32 days (mean) after surgery five patients were treated with systemic adrenocortical corticosteroids: four with fluocortolone 5-20 mg/day, one with methylprednisolone $30 \mathrm{mg} /$ day. Only one patient received 10 and $20 \mathrm{mg}$ fluocortolone per day, respectively, 1924 and 1994 days after surgery. The disease activity was assessed by the Crohn's disease activity index (CDAI), a numerical index calculated from the number of liquid or very soft stools, abdominal pain, general well being, inflammatory complications, abdominal mass, body weight, packed cell volume, and intake of loperamide or opiates. ${ }^{19}$

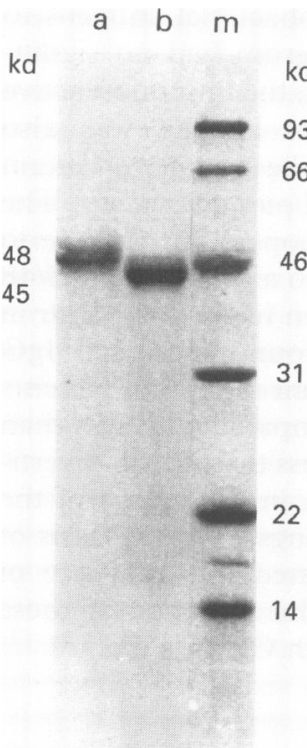

Figure 1: Homogeneity of 48 and 45 kilodalton ( $a$ and $b$ respectively) gel purified protein antigen purified protein antige
shown by SDS-gel electrophoresis followed by western blotting and amido black staining. The mixture of $a$ and $b$ (1:1) constituted 45/48 kilodalton doublet antigen for ELISA. $m=$ molecular marker

Sodium dodecyl sulphate-polyacrylamide gel electrophoresis (SDS-PAGE)

SDS-PAGE was performed in a discontinuous buffer system according to the method of Laemmli $^{20}$ by using a $12 \%(w / v)$ separating gel containing $0 \cdot 1 \%(\mathrm{w} / \mathrm{v})$ SDS. Fifteen $\mu \mathrm{g}$ protein were applied per $810 \mathrm{~mm}^{2}$ per run.

\section{Immunoblot assay}

The cytosol as well as the plasma membrane fraction of $M$ tuberculosis were subjected to SDS-PAGE, and the separated bands were electrophoretically transferred to nitrocellulose using the method of Towbin et al. ${ }^{21}$ After washing, the nitrocellulose sheets were incubated with diluted patients' serum samples (1:100) and then probed with horseradish peroxidase conjugated affinity purified secondary goat antihuman IgG (Cappel Laboratories, West Chester, PA, USA) as described. ${ }^{22}$ In each experiment low molecular weight standards (lysozyme 14 kilodalton, soybean trypsin inhibitor 22 kilodalton, ovalbumin 45 kilodalton, bovine serum albumin 66 kilodalton, phosphorylase B 93 kilodalton; Bio-Rad Laboratories, Richmond, CA, USA) were subjected to these procedures as described above and stained with amido black to facilitate the identification of the antigenic moieties of the $45 / 48$ kilodalton doublet antigen reactive to serum. The immunoblot assays were qualitatively graded by comparison with the 66 kilodalton band by two of the authors independently with identical results. For verification a third blinded evaluation was performed by a third investigator.

\section{Purification of subcellular fractions of $\mathrm{M}$ tuberculosis}

The cytosol (Cyt) and the plasma membrane fraction (P90) of $M$ tuberculosis strain RIVM 7114, Bilthoven, the Netherlands, were prepared according to the modified method of Das et $a l^{23}$ as described by Rambukkana et al..$^{24}$

\section{Purification of the 45/48 kilodalton doublet antigen of $\mathrm{M}$ tuberculosis}

A sonicated preparation of $M$ tuberculosis was applied to a preparative SDS-PAGE by using a $12 \%(\mathrm{w} / \mathrm{v})$ separating gel containing $0 \cdot 1 \%$ (w/v) SDS. Slices, $2 \mathrm{~mm}$, were cut from the gel in the area of 45 and 48 kilodalton. Bound proteins were eluted by either electroelution or diffusion in distilled water. The homogeneity of the antigen preparations was tested by SDSPAGE followed by electrophoretic transfer to nitrocellulose, staining with amido black and also incubation with pool serum from patients with Crohn's disease, which were known to have antibody activities to the $45 / 48$ kilodalton doublet antigen in a western blot assay (Fig 1). The eluted 45/48 kilodalton doublet antigen was extensively dialysed against phosphate buffered saline (PBS), $\mathrm{pH} 7 \cdot 4$, and stored at $-20^{\circ} \mathrm{C}$. This gel purified preparation was used for ELISA.
ELISA with the 45/48 kilodalton doublet antigen of $\mathrm{M}$ tuberculosis

ELISA serology was performed according to an optimum evaluated standard method $^{22}$ 


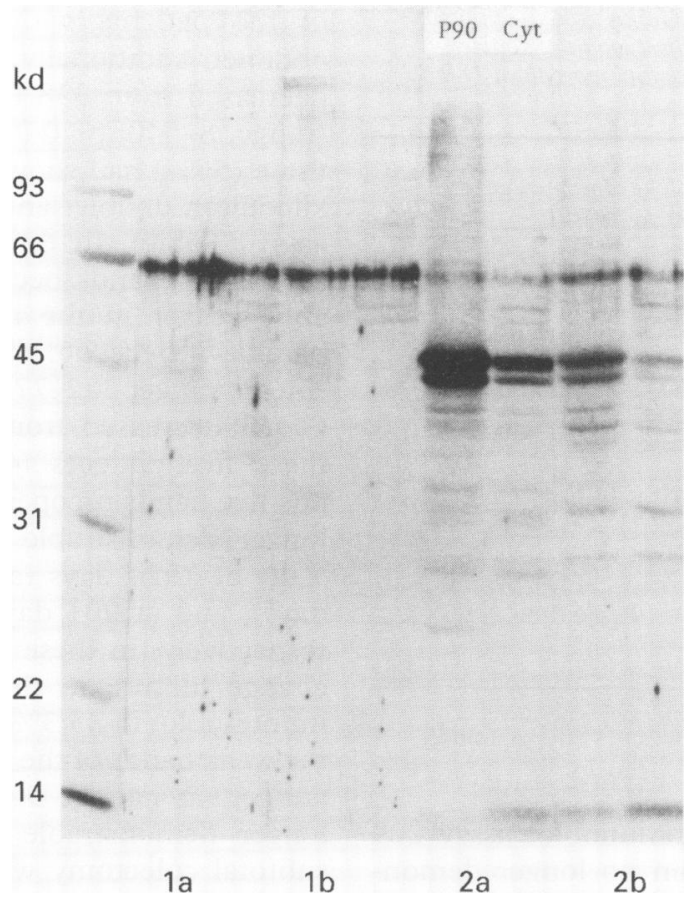

Figure 2: Immunoblot assay using the plasma membrane fraction (P90) and cytosol (Cyt) of M tuberculosis for detection of IgG directed to the 45/48 kilodalton doublet antigen in serum of patients with Crohn's disease. $P 90$ means the plasma membrane fraction yielded by centrifugation at $90000 \mathrm{~g}$. P90 and Cyt apply to each of the four examples of Crohn's disease serum samples examined in duplicate. 1 $a+b$ : Two negative samples before and 613 days after surgery. $2 a$ : Strong bands at 45/48 kilodalton before surgery (patient 2 in Table). $2 b$ : Weaker bands 772 days after surgery (patient 2 in Table).

using the 45/48 kilodalton doublet antigen, which was SDS-PAGE purified from the whole sonicated preparation of broken organisms of $M$ tuberculosis as already described.

The microdilution plates (Greiner, Denmark) were coated with a pre-evaluated optimal amount of $0.5 \mu \mathrm{g}$ protein of the $45 / 48$ kilodalton doublet antigen per well in $0.067 \mathrm{M}$ PBS, $\mathrm{pH} 7 \cdot 4$, and incubated for two hours at $37^{\circ} \mathrm{C}$. The plates were washed thoroughly with PBS containing $0.05 \%(\mathrm{v} / \mathrm{v})$ TWEEN 20 (PBS-TWEEN 20); this wash was followed by further incubation with $2 \%(\mathrm{w} / \mathrm{v})$ bovine serum albumin in PBS-TWEEN 20 for two hours and a subsequent washing step. Serial dilutions of human serum up to $1: 1600$ in $10 \%(\mathrm{v} / \mathrm{v})$ normal goat serum and $0 \cdot 1 \%(\mathrm{v} / \mathrm{v})$ TWEEN 20 were added to achieve antigen antibody binding by incubation for one hour at $37^{\circ} \mathrm{C}$; this procedure was followed by thorough washing. The plates were further incubated for one hour at $37^{\circ} \mathrm{C}$ with pre-evaluated dilutions of horseradish peroxidase conjugated affinity purified secondary goat antihuman IgG in PBS containing $10 \%(\mathrm{v} / \mathrm{v})$ normal goat serum and $0 \cdot 1 \%$ (v/v) TWEEN 20. After washing, the enzyme activities were shown with the substrate $3,3^{\prime}, 5,5^{\prime}$-tetramethylbenzidine plus dimethyl sulphoxide and $\mathrm{H}_{2} \mathrm{O}_{2}$ by continuing the reaction for 15 minutes at $25^{\circ} \mathrm{C}$. The colour development was stopped with $50 \mu$ l of $2 \mathrm{~N} \mathrm{H}_{2} \mathrm{SO}_{4}$, and optical density was measured at $450 \mathrm{~nm}$ in a Bio-Rad ELISA reader coupled to a Macintosh computer. The end point titres of IgG antibody in the serum of patients and controls were determined using serial dilutions of the samples followed by extrapolating the titration curve to an optical density value equal to or greater than two times that for the reagent blanks. Comparing the titration curves of serum IgG antibody to $45 / 48$ kilodalton doublet antigen in the patients and control serum, resulted in the maximum difference in optical densities in these two groups being seen in 1:400 dilution of serum.

The laboratory evaluations were carried out in the Section of Experimental Dermatopathology, Institute of Pathology of the University of Amsterdam.

\section{STATISTICAL ANALYSIS}

The CDAI before and after surgery was analysed with the paired Student's $t$ test. The exact Fisher's test was applied for comparison of the results of the immunoblot assays of Crohn's disease patients with each control group.

\section{Results}

Western blot analysis of serum showed IgG directed to the $45 / 48$ kilodalton doublet antigen of $M$ tuberculosis in 11 of 17 patients with Crohn's disease $(64.7 \%)$ and one patient each with ulcerative colitis $(10 \%)$ and carcinoma of the colon $(5 \%)$. Figure 2 shows two negative serum samples $(1 \mathrm{a}+\mathrm{b})$ and two samples with strong bands of the 45/48 kilodalton doublet antigen $(2 a+b)$ from patients with Crohn's disease. These antibodies were not detectable in 10 healthy subjects. Comparison of the results of Crohn's disease patients with each control group resulted in a statistical significance of $\mathrm{p}=0 \cdot 0000236$.

Forty five samples obtained from the 17 patients with Crohn's disease were investigated with the immunoblot assay as well as the ELISA. Both assays yielded positive results in 20 samples and negative results in 16 , but different results in nine samples: five samples were reactive in the immunoblot assay but unreactive in the ELISA, four samples were negative in the immunoblot assay but gave a positive reaction in the ELISA. Altogether, both assays yielded identical results in $80 \%$.

Within a mean period of 284 days after intestinal resection 28 samples were obtained from these 17 patients with Crohn's disease. The CDAI decreased significantly from an average of 343 (range, 102-679) to 168 (range, 10-376; $\mathrm{p}<0.0005)$. The first follow up samples were obtained from all patients a mean of 75 days after surgery (range, 5-613 days) and showed no significant change in the immunoblot assay: of the 11 positive samples (10 preoperatively, one postoperatively) the bands of the 45/48 kilodalton doublet antigen remained unchanged in three patients, whereas the bands of the other eight samples showed changes in intensity compared with the 66 kilodalton band. In addition, $75 \%$ of all samples showed an identical antibody time course in the immunoblot assay and the ELISA. In one patient the antibodies were not detected before surgery and nine days afterwards; they became 
Serology and disease activity in Crohn's disease patients with serum IgG against the $45 / 48$ kilodalton doublet antigen of $\mathrm{M}$ tuberculosis before and more than 180 days after resection of intestine

\begin{tabular}{|c|c|c|c|c|}
\hline Patient & $\begin{array}{l}\text { Interval after } \\
\text { resection of } \\
\text { intestine (days) }\end{array}$ & $C D A I^{\star}$ & $\begin{array}{l}\text { Immunoblot } \\
\text { assayt }\end{array}$ & ELISA† \\
\hline 1 & $\begin{array}{r}0 \\
13 \\
1924 \\
1994\end{array}$ & $\begin{array}{r}337 \\
230 \\
48 \\
310\end{array}$ & $\begin{array}{l}(+) \\
+ \\
- \\
-\end{array}$ & $\begin{array}{l}- \\
+ \\
- \\
-\end{array}$ \\
\hline 2 & $\begin{array}{r}0 \\
208 \\
772\end{array}$ & $\begin{array}{r}102 \\
10 \\
8\end{array}$ & $\begin{array}{l}++ \\
++1+ \\
++1+\end{array}$ & $\begin{array}{l}++ \\
++1+ \\
++1+\end{array}$ \\
\hline 3 & $\begin{array}{r}0 \\
25 \\
250 \\
276\end{array}$ & $\begin{array}{l}679 \\
279 \\
117 \\
123\end{array}$ & $\begin{array}{l}++ \\
++ \\
++1+ \\
++1+\end{array}$ & $\begin{array}{l}++ \\
++ \\
++1+ \\
-\end{array}$ \\
\hline 4 & $\begin{array}{r}0 \\
20 \\
202\end{array}$ & $\begin{array}{r}378 \\
119 \\
34\end{array}$ & $\begin{array}{l}+ \\
+ \\
+/(+)\end{array}$ & $\begin{array}{l}(+) \\
+ \\
(+)\end{array}$ \\
\hline 5 & $\begin{array}{r}0 \\
12 \\
201\end{array}$ & $\begin{array}{l}502 \\
122 \\
135\end{array}$ & $\begin{array}{l}(+) \\
(+) \\
-\end{array}$ & $\begin{array}{l}+ \\
+ \\
+\end{array}$ \\
\hline
\end{tabular}

${ }^{\star} \mathrm{CDAI}=$ Crohn's disease activity index. $\uparrow-$ negative, $(+)$ weak positive, + distinct positive, ++ strong positive, $+/(+),++/+$ intermediate values.

weakly positive in the immunoblot assay 209 days later, but were again no longer demonstrable after a further 76 days. The ELISA remained continuously negative.

After a mean postoperative interval of 538 days (range, 200-1924 days) samples of nine

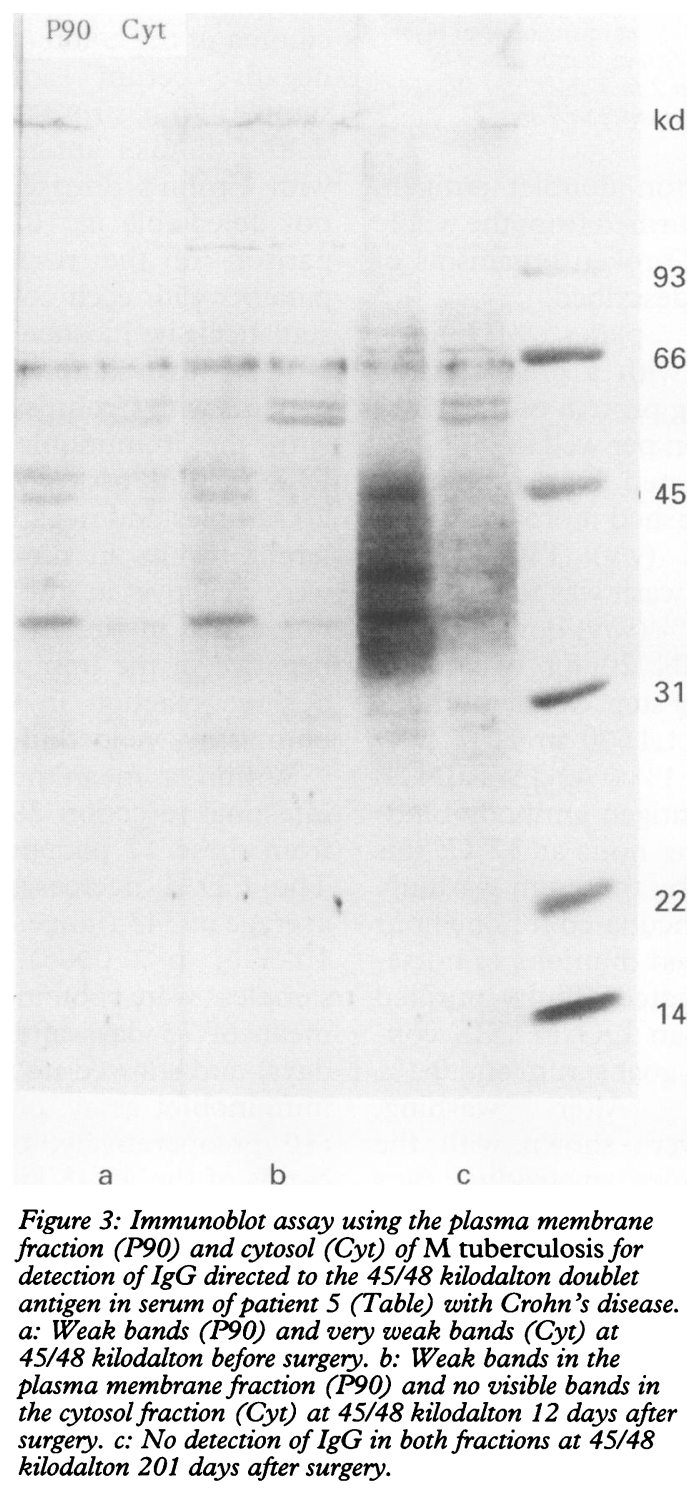

of the patients with Crohn's disease were obtained additionally, in these the CDAI was decreased from 338 (range, 102-679) to 144 (range, $8-540 ; p<0.05$ ). Preoperatively five of these $(56 \%)$ had shown IgG against the $45 / 48$ kilodalton doublet antigen in the immunoblot assay (Table). In three of these five patients $(60 \%)$ the bands became slightly but noticeably weaker in the immunoblot assay compared with the 66 kilodalton band 342 days (mean; range, 202-772 days) after surgery, the CDAI decreased from 386 to 55 . In two of these five patients $(40 \%)$, who had weakly positive bands preoperatively, the IgG were no longer demonstrable in the immunoblotting assay at 1924 days (and additionally at 1994 days), and at 201 days after bowel resection, respectively. In these five positive patients the change in titre in the ELISA paralleled the immunoblot in $83.3 \%$ (Table). Figure 3 shows the weak bands of the $45 / 48$ kilodalton doublet antigen in patient 5 (Table). They were no longer demonstrable 201 days after further subtotal colectomy with retention of the sigmoid colon and rectum, at which time the CDAI had decreased from 502 to 135 . The other patient (number 1 in Table) had a resection of the anastomosis after ileotransversostomy, 1924 days after that the CDAI had decreased from 337 to 48, however, 70 days later the CDAI increased again to 310 without a change in the immunoblot assay and the ELISA.

None of these five patients had any history of tuberculosis. Multiple $x$ rays of the thorax performed during a period of $7.5(5 \cdot 0)$ years (mean (SD); range $0.05-10.7$ ) showed no radiological signs of tuberculosis in four patients. Only one patient (number 4 in Table) showed scarred residues of a minor specific infection but had a negative skin test with tuberculin in autumn 1993.

The immunoblot assay showed no positive correlation with the immunosuppressive treatment, or with the duration, intestinal involvement as well as the activity of Crohn's disease. The preoperatively positive serum samples that were tested again after more than 180 days after intestinal resection yielded, however, a positive correlation with the CDAI in the immunoblot assay.

\section{Discussion}

On the basis of an immunoblot assay and an ELISA, specific IgG directed to the $45 / 48$ kilodalton doublet antigen of $M$ tuberculosis were demonstrable in $64.7 \%$ and $58.8 \%$, respectively, of patients with Crohn's disease, significantly higher than in controls and in other intestinal diseases. These data confirm the results of Das et al, ${ }^{18}$ who showed that the immunoblot assay has a specificity of about $80-90 \%$ for patients with Crohn's disease, whereas the sensitivity of $65 \%$ is rather low. The 45/48 kilodalton doublet antigen was purified from tubercle bacilli because $M$ paratuberculosis was not available in sufficient quantity. Furthermore, the $45 / 48$ kilodalton doublet antigen belongs to the family of 
mycobacterial immuno cross reactive antigenic components, ${ }^{22}$ which is also present in $M$ paratuberculosis as shown by immunoblotting using serum of Crohn's patients (unpublished finding). In the case of an unclear histological diagnosis this assay may be useful for differentiation of ulcerative colitis from Crohn's disease as well as for follow up.

An immunoblot assay using the protoplasmic and surface antigen of $M$ paratuberculosis, which was recently described by Tanaka et $a l^{25}$ shows certain parallels to our results. A strong IgG response against a 45 kilodalton antigen from the $M$ paratuberculosis protoplasmic antigen was found in $40 \%$ of the 10 Crohn's disease patients, and it was also weakly present in a further $20 \%$. A weak response, however, was also given by four ulcerative colitis $(40 \%)$ and one of the noninflammatory bowel disease patients $(10 \%)$.

Using the western blot technique Elsaghier et $a l^{26}$ were also able to detect antibodies binding to the 38 kilodalton band of the extract of $M$ paratuberculosis in $57 \%$ of Crohn's disease patients. In addition, antibody levels to the 24 and 18 kilodalton bands assessed by ELISA were significantly increased in $53 \%$ of the patients with Crohn's disease compared with controls. More recently Stainsby et al ${ }^{7}$ failed to detect increased antibodies to crude antigens of various disrupted mycobacteria, which is in accordance with earlier studies. ${ }^{1-6}$ A distinct subset of $25 \%$ of patients with active Crohn's disease, however, had increased IgG concentrations compared with controls.

Sanderson $e a^{27}$ were able to detect DNA of $M$ paratuberculosis in tissues in $65 \%$ of patients with Crohn's disease, but only in $4.3 \%$ of patients with ulcerative colitis and $12.5 \%$ of control patients. Their data obtained with a highly specific polymerase chain reaction supplement ideally with our serological results.

The purpose of our investigation was to evaluate the follow up of serum antibodies specific for Crohn's disease after the resection of diseased intestinal segments. Seventy five days after surgery the IgG were essentially unchanged in the immunoblot assay and the ELISA. After more than 180 days, however, an antibody decrease occurred in all five patients studied at that interval, and in $40 \%$ these antibodies were no longer demonstrable. In these there was a positive correlation between the specific antibodies and the CDAI. But there was one exception in a patient in whom the CDAI increased again 70 days later without the detection of specific antibodies (Table). Tuberculosis was not responsible for the immunoreactivity of these five patients. A nonspecific decrease in titres of antibodies to the $45 / 48$ kilodalton doublet antigen caused by an artefact, for example, freeze thawing or dilution of serum could be excluded by the comparison with the 66 kilodalton band.

In summary, on the basis of a mycobacterial doublet antigen, a serological assay with high specificity for Crohn's disease was developed. The antibody response was reduced 200 to 1994 days after the resection of diseased intestinal segments in Crohn's disease, and was no longer demonstrable in $40 \%$. This supports a mycobacterial aetiology of Crohn's disease. A prognostic significance of this assay may be speculated, but can only be confirmed on the basis of more data and longer follow up. Of special interest would be the effect of appropriate antimycobacterial chemotherapy on this antibody response.

This work was supported by the Faculty of Medicine (AP/46), University of Amsterdam, the Netherlands. The authors thank Dr T Burke West for his review of the manu The authors thank Dr Burke West for his review of the manuscript, and HannesHeine-University Düsseldorf, Germany, for statistical analysis.

1 Morganroth J, Watson DW. Sensitivity to atypical mycobacterial antigens in patients with Crohn's disease. Am f Dig Dis 1970; 15: 653-7.

2 Thayer WR Jr, Fixa B, Komarkova O, Charland C, Field CE. Skin test reactivity in inflammatory bowel disease in the United States and Czechoslovakia. Dig Dis 1978; 23: 337-40.

3 Matthews N, Mayberry JF, Rhodes J, Neale L, Munro J, Wensinck F, et al. Agglutinins to bacteria in Crohn's disease. Gut 1980; 21: 376-80.

4 Elliott PR, Lennard-Jones JE, Burnham WR, White $S$, Stanford JL. Further data on skin testing with myco-
bacterial antigens in inflammatory bowel disease [Letter]. bacterial antigens in inflam
Lancet 1980; ii: $483-4$.

5 Lefler HM, Marshall V, Lanspa SJ, Tremaine WJ. Detection of serum antibodies to Mycobacterium paratuberculosis from patients with Crohn's disease: a blinded study [Abstract]. Gastroenterology 1985; 88: 1470 .

6 Haagsma J, Mulder CJJ, Eger A, Tytgat GNJ. A study of antibodies to Mycobacterium paratuberculosis in inflammatory bowel disease. Preliminary results. In: MacDermott RP, ed. Inflammatory bowel disease: current status and future approach. Amsterdam: Elsevier Science, 1988: 539-41.

7 Stainsby KJ, Lowes JR, Allan RN, Ibbotson JP. Antibodies to Mycobacterium paratuberculosis and nine species of environmental mycobacteria in Crohn's disease and control subjects. Gut 1993; 34: 371-4.

8 Blaser MJ, Miller RA, Lacher J, Singleton JW. Patients with active Crohn's disease have elevated serum antibodies to antigens of seven enteric bacterial pathogens. Gastroenterology 1984; 87: 888-94.

9 Kobayashi K, Brown WR, Brennan PJ, Blaser MJ. Serum antibodies to mycobacterial antigens in active Crohn's disease. Gastroenterology 1988; 94: 1404-11.

$10 \mathrm{McF}$ adden J, Houdayer C. No evidence for antibodies to mycobacterial A60 antigen in Crohn's disease sera by enzyme-linked immunoabsorbent assay (ELISA). f Med Microbiol 1988; 25: 295-8.

11 Funakoshi O. Mycobacterial aetiology of Crohn's disease. fpn f Gastroenterol 1988; 85: 1340-6.

12 Jiwa NM, Mulder CJJ, van den Berg FM, Tytgat GNJ, Haagsma J, Walboomers JMM. Elevated IgG to mycobacterial PPD's in Crohn's disease. In: MacDermott RP, ed. Inflammatory bowel disease: current status and future approach. Amsterdam: Elsevier Science, 1988: 543-6.

13 Grange JM, Gibson J, Nassau E, Kardjito T. Enzymelinked immunosorbent assay (ELISA): a study of antibodies to Mycobacterium tuberculosis in the IgG, IgA and IgM classes in tuberculosis, sarcoidosis and Crohn's disease. Tubercle 1980; 61: 145-52.

14 Thayer WR Jr, Coutu JA, Chiodini RJ, van Kruiningen HJ, Merkal RS. Possible role of mycobacteria in inflammatory bowel disease. II. Mycobacterial antibodies in Crohn's disease. Dig Dis Sci 1984; 29: 1080-5.

15 Cho S-N, Brennan PJ, Yoshimura HH, Korelitz BI, Graham DY. Mycobacterial aetiology of Crohn's disease: serologic study using common mycobacterial antigens and a species-specific glycolipid antigen from Mycobacterium paratuberculosis. Gut 1986; 27: 1353-6.

16 Haga Y, Funakoshi I, Nakajima H, Sano M, Murata A, Munakata $\mathrm{A}$, et al. Antibodies to Mycobacterium paratuberculosis in sera of patients with Crohn's disease. Digestive Organs Immunology 1986; 17: 100-3.

17 Whitehead JT. Comparison of Mycobacterium paratuberculosis with other Mycobacterium spp (including an isolate from a patient with Crohn's disease) by polyacrylamide gel electrophoresis and immunoblotting acrylamide gel electrophoresis and immunoblotting the second international Colloquium on Paratuberculosis, 1988 Sep 22-23, Maisons-Alfort, France. Maisons-Alfort: Sep 22-23, Maisons-Alfort, France. Maisons-Alfort: 254-64.

18 Das PK, Blaauwgeers JLG, Slob AW, Yong SL, Rambukkana A. Mycobacterial antibody (myc-ab) response in relation to Crohn's disease (CD). Gastroenterology 1989; 96: A111.

19 Best WR, Becktel JM, Singleton JW, Kern F Jr. Development of a Crohn's disease activity index. Gastroenterology 1976; 70: 439-44.

20 Laemmli UK. Cleavage of structural proteins during the assembly of the head of bacteriophage T4. Nature 1970; 227: $680-5$. 
21 Towbin H, Staehelin T, Gordon J. Electrophoretic transfer of proteins from polyacrylamide gels to nitrocellulose sheets: procedure and some applications. Proc Natl Acad Sci USA 1979; 76: 4350-4.

22 Das PK, Rambukkana A, Baas JG, Groothius DG, Halperin M. En Halperin $M$. Enzyme-linked imssay for distinguishing serological responses of lepromatous and tuberculoid leprosies to the 29/33-kilodalton 64-kilodalton antigens of Mycobacterium $379-82$.

23 Das PK, Ibrahim AA, Binkhuysen F, Thi Hué P, Qui TH, Rangarajan $\mathrm{R}$, et al. The use of subcellular components of BCG for studying host-mycobacterium interaction in relation to leprosy. Ann Inst Pasteur Immunol 1982; 133D: 41-59.
24 Rambukkana A, Das PK, Chand A, Baas JG, Groothuis DG, Kolk AHJ. Subcellular distribution of monoclonal antibody defined epitopes on immunodominant Mycobacterium tuberculosis proteins in the $30-\mathrm{kDa}$ region: identification and localization of $29 / 33-\mathrm{kDa}$ doublet proteins on mycobacterial cell wall. Scand $\mathcal{f}$ Immunol 1991; 33: 763-75.

25 Tanaka K, Wilks $M$, Coates PJ, Farthing MJG, WalkerSmith JA, Tabaqchali S. Mycobacterium paratuberculosis and Crohn's disease. Gut 1991; 32: 43-5.

26 Elsaghier A, Prantera C, Moreno C, Ivanyi J. Antibodies to Mycobacterium paratuberculosis-specific protein antigens 27 Sanderson JD, Moss MT, Tizard MLV, Hermon-Taylor J. Mycobacterium paratuberculosis DNA in Crohn's disease tissue. Gut 1992; 33: 890-6. 